\title{
Guidelines
}

European

Thyroid Journal
Eur Thyroid J 2012;1:142-147

DOI: $\underline{10.1159 / 000342982}$
Received: July 5, 2012

Accepted after revision: August 27, 2012

Published online: October 4, 2012

\section{European Thyroid Association Guidelines for the Management of Familial and Persistent Sporadic Non-Autoimmune Hyperthyroidism Caused by Thyroid- Stimulating Hormone Receptor Germline Mutations}

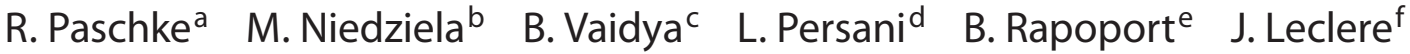 \\ a Department of Endocrinology and Nephrology, Leipzig University, Leipzig, Germany; ${ }^{b}$ Department of Pediatric \\ Endocrinology and Rheumatology, Poznan University of Medical Sciences, Poznan, Poland; ' Department of Endocrinology, \\ Royal Devon and Exeter Hospital, Peninsula Medical School, Exeter, UK; ${ }^{d}$ Department of Clinical Sciences, and Community \\ Health, University of Milan, and Istituto Auxologico Italiano, Milan, Italy; ${ }^{\text {e} A u t o i m m u n e ~ D i s e a s e ~ U n i t, ~ C e d a r s-S i n a i ~ R e s e a r c h ~}$ \\ Institute and School of Medicine, University of California, Los Angeles, Calif., USA; 'Centre Hospitalier Universitaire de Nancy, \\ Nancy, France
}

\section{Key Words}

Non-autoimmune hyperthyroidism $\cdot T S H R \cdot$ Germline mutations · Guidelines

\begin{abstract}
All cases of familial thyrotoxicosis with absence of evidence of autoimmunity and all children with persistent isolated neonatal hyperthyroidism should be evaluated for familial non-autoimmune autosomal dominant hyperthyroidism (FNAH) or persistent sporadic non-autoimmune hyperthyroidism (PSNAH). First, all index patients should be analysed for the presence/absence of a thyroid-stimulating hormone (TSH) receptor (TSHR) germline mutation, and if they display a TSHR germline mutation, all other family members including asymptomatic and euthyroid family members should also be analysed. A functional characterization of all new $T S H R$ mutations is necessary. Appropriate ablative therapy is recommended to avoid relapses of hyperthyroidism and its consequences, especially in children. Therefore, in children the diagnosis of FNAH or PSNAH needs to be established as early as possible in the presence of the clinical hallmarks of the disease.

Copyright $\odot 2012$ European Thyroid Association Published by S. Karger AG, Basel
\end{abstract}

\section{KARGER}

Fax +41613061234

E-Mail karger@karger.ch

www.karger.com
(C) 2012 European Thyroid Association

Published by S. Karger AG, Basel

2235-0640/12/0013-0142\$38.00/0

Accessible online at:

www.karger.com/etj

\section{Introduction}

Familial non-autoimmune autosomal dominant hyperthyroidism (FNAH) and persistent sporadic congenital non-autoimmune hyperthyroidism (PSNAH) are rare forms of hyperthyroidism caused by germline mutations in the thyroid-stimulating hormone (TSH) receptor (TSHR) gene. At present, there are no guidelines for the management of these conditions. The diagnosis of this rare form of hyperthyroidism allows appropriate therapy of the disease with the likely consequence of fewer relapses of hyperthyroidism. Moreover, it allows genetic counseling and presymptomatic diagnosis. This guideline aims to provide evidence-based recommendations for timely diagnosis and optimal treatment of these conditions.

\section{Methods}

The taskforce for this guideline was instituted by the executive committee of the European Thyroid Association. R. Paschke was selected to lead the task force. References were searched in the TSH Receptor Mutation Database III (http://tsh-receptor-mutationdatabase.org), the Online Mendelian Inheritance in Man database (OMIM 609152) and PubMed using the following search terms: hy- 
perthyroidism, autosomal, genetics, familial, sporadic and TSHR. The Grading of Recommendations Assessment, Development and Evaluation system was used to grade the quality of evidence and the strength of recommendations $[1,2]$. It consists of 2 scorings, namely quality of evidence (low $=+$; moderate $=++$; high $=+++$ ) and strength of recommendation (strong; weak). The draft guideline was posted on the European Thyroid Association website for 1 month for its members to comment. The comments were discussed in the guideline taskforce and the guideline was modified accordingly before final approval by the guideline committee and the European Thyroid Association executive committee.

\section{Background}

\section{Definitions}

Familial Non-Autoimmune Autosomal Dominant Hyperthyroidism

FNAH is caused by constitutively activating germline mutations in the TSHR gene (TSH Receptor Mutation Database III, OMIM 609152).

This disorder is characterized by:

(1) A positive family history of non-autoimmune hyperthyroidism with dominant inheritance.

(2) An absence of clinical (ophthalmopathy or dermopathy) or other stigmata of autoimmunity [TSHR antibodies, thyroid peroxidase (TPO) antibodies, hypoechoic pattern at ultrasound and lymphocytic infiltration on histology]. The presence of TPO and thyroglobulin antibodies has been reported in a few cases [3-5], consistent with a high prevalence of these antibodies in the general population.

(3) The presence of goiter, which is generally diffuse in children and tends to become multinodular later in life [3-17] (http://tsh-receptor-mutation-database. org). Very rarely, goiter is absent [18].

(4) A highly variable age of manifestation of hyperthyroidism, which ranges between the neonatal period [8] and 60 years [14]. It is also highly variable within the same family, for example 10-36 years in the Nancy family [19], 18 months to 53 years in the Reims family [19], 2-21 years in the Cardiff family [3] and 4-60 years in the family reported by Karges et al. [14] (http:// tsh-receptor-mutation-database.org).

(5)Hyperthyroidism, which may vary from mild [20] or subclinical (two members in the Nancy family [19] and one member in the family of Vaidya et al. [4]) to severe (see http://tsh-receptor-mutation-database.org).

(6) Recurrences after withdrawal of antithyroid drug therapy, non-ablative radioiodine treatment or partial thyroidectomy [21].

ETA Guidelines for the Management of

Non-Autoimmune Hyperthyroidism
Persistent Sporadic Congenital Non-Autoimmune Hyperthyroidisim

PSNAH with onset during the neonatal period (sporadic congenital non-autoimmune hyperthyroidism) or even later has been found to be caused by sporadic (de novo) germline mutations in the TSHR gene [22-25]. It is characterized by:

(1) An earlier (neonatal period to 11 months) and more severe onset than FNAH [26-28].

(2) Goiter in all except 1 individual. The goiters are mostly diffuse at the onset and become progressively nodular with increasing duration of the disease [29, 30].

(3) An absence of TSHR or TPO antibodies, lymphocytic infiltration in the thyroid gland on cytology/histology or hypoechogenicity on thyroid ultrasound [26].

(4) Isolated hyperthyroidism (i.e. no association with gonadotropin-independent sexual precocity, café-au-lait skin lesions and fibrous dysplasia of bone, as in typical McCune-Albright syndrome).

(5) Negative family history of non-autoimmune hyperthyroidism.

(6) Various consequences of prolonged neonatal hyperthyroidism, such as craniosynostosis or low birth weight (TSH Receptor Mutation Database III, OMIM 609152).

(7)Relapses of hyperthyroidism following withdrawal of antithyroid drugs and also after subtotal thyroidectomy. Radioiodine in addition to surgery is necessary to induce euthyroidism in most cases [21].

(8) An absence of inflammatory ophthalmopathy. However, the presence of noninflammatory ocular signs (for example, proptosis) does not exclude the diagnosis of PSNAH [31].

\section{Prevalence}

To date, 27 families with FNAH [3-7, 9-20, 32-40] and 15 cases with PSNAH have been published $[8,22-29,41-$ 49]. Women are affected more frequently by the familial form ( 83 women compared to 69 men), but not by the sporadic form (TSH Receptor Mutation Database III, OMIM 609152). Neonatal thyrotoxicosis is rare and nearly always associated with maternal Graves' disease if the thyrotoxicosis in the newborn is transient.

\section{Genetic Etiology and Pathophysiology}

FNAH and PSNAH are caused by constitutively activating TSHR germline mutations [31, 50,51]. This gene is encoded by 10 exons which extend over $60 \mathrm{~kb}$ on chromosome 14q31 (OMIM 603372). The phenotype of a family 
with non-autoimmune autosomal dominant hyperthyroidism (the Nancy family) was first described by Thomas et al. [32] in 1982. In this family, thyrotoxicosis without evidence of Graves' disease was observed in 16 of the 48 family members examined. Twelve years after the initial description of non-autoimmune autosomal dominant hyperthyroidism in the Nancy family, the V509A germline mutation, which displayed a 3-fold basal cAMP increment over the wild-type TSHR, was identified in this family [19].

Upon binding to its receptor, TSH exerts its action via both the cAMP and inositol phosphate pathways. The main signal transduction pathway involves the activation of adenylate cyclase through $G$ protein coupling and the intracellular production of cAMP. The cAMP pathway has been shown to stimulate thyroid hormone secretion and growth of thyrocytes. Constitutive activation of the cAMP pathway results in alterations of both function and proliferation of the thyroid cells.

Further germline TSHR mutations associated with FNAH also show increased basal cAMP compared to the wild-type TSHR, ranging from 1.5- to 5-fold the basal levels in the families and up to 7-fold for the sporadic TSHR mutations [30] (TSH receptor Mutation Database III). Members of the same family harbouring the same TSHR germline mutation show large differences in disease onset $[33,34,36,48]$. Therefore, besides the constitutive activation of the cAMP pathway, most likely additional factors, for example genetic background and/or iodine intake, may modify the phenotypic expression [52].

The functional in vitro characterization of all new TSHR mutations by linear regression analysis of constitutive activity as a function of TSHR expression is recommended if the constitutive activity is only slightly increased [53]. The reason for this recommendation is that besides large variations in the extent of constitutive activity for several mutations characterized in different laboratories, 2 TSHR germline mutations and 4 somatic TSHR germline mutations all previously published as constitutively active did not reveal constitutive activity in COS cells when later analysed by the linear regression approach to determine constitutive activity as a function of TSHR expression $[54,55]$. Therefore, TSHR mutations with only slightly increased constitutive activity in particular should be characterized by a reproducible method which controls for one of the most important variables, e.g. receptor expression. Moreover, silent TSHR germline mutations are known [56].

\section{Recommendations}

\section{Diagnostic Principles}

When Should FNAH Be Suspected?

To select the appropriate therapy and avoid frequent relapses and their consequences, especially in children, the diagnosis of FNAH should be considered in all cases of familial thyrotoxicosis with the presence of at least criteria 1, 2 and 3:

(1) a history of familial non-autoimmune thyrotoxicosis with dominant inheritance;

(2) absence of evidence of autoimmunity (no inflammatory signs of ophthalmopathy or dermopathy, absence of TSHR antibodies, no ultrasound signs of autoimmunity, e.g. hypoechogenicity, absence of lymphocytic infiltration on histology);

(3) isolated hyperthyroidism confirmed by high serum level of free T4 and low serum level of TSH or subclinical hyperthyroidism (only suppressed TSH);

(4) moderate diffuse goiter in children or multinodular goiter in adulthood (but the absence of goiter does not exclude the diagnosis), and

(5) recurrence after withdrawal of medical treatment or non-ablative surgical or radioiodine treatment.

Quality of the evidence: high (+++); strength of recommendations: strong.

\section{When Should PSNAH Be Suspected?}

To select the appropriate therapy and avoid frequent relapses and their consequences in children, the diagnosis of PSNAH should be considered in the presence of at least criteria 1, 2 and 3 :

(1) negative family history of hyperthyroidism;

(2) absence of TSHR antibodies, no ultrasound signs of autoimmunity (hypoechogenicity);

(3) persistent neonatal isolated hyperthyroidism (still hyperthyroid without treatment after 6 weeks) and recurrence of neonatal hyperthyroidism after antithyroid drug withdrawal, subtotal thyroidectomy or radioiodine treatment, and

(4) diffuse goiter in the neonatal period or nodular goiter later on.

Quality of the evidence: high (+++); strength of recommendations: strong.

The diagnostic principles for PSNAH resemble those for FNAH. However, the clinical severity of hyperthyroidism is often more pronounced in PSNAH than in FNAH, and a family history of thyrotoxicosis is absent in PSNAH. FNAH, which is more frequent than PSNAH, should especially be suspected in patients with a family
Paschke/Niedziela/Vaidya/Persani/ Rapoport/Leclere 
history of hyperthyroidism (so called TSHR antibodynegative Graves' disease [57]).

Almost all reported patients with PSNAH became symptomatic within the 1st year of life $[30,43]$. The majority of newborns with non-autoimmune congenital hyperthyroidism were born prematurely and had lower birth weight $[4,30,49]$. Bone age is commonly advanced at the time of diagnosis. The finding of an increased growth velocity has also been correlated to an increase in circulating insulin-like growth factor 1 that reverted to normal after the cure of hyperthyroidism [11]. All these features (prematurity, low birth weight and advanced bone age) are typical for congenital hyperthyroidism but are not specific for PSNAH. Craniosynostosis was present in half the patients [30,49]. Symptoms of developmental impairment (such as mental retardation and speech disturbances) and hydrocephalus were also present in almost half of the affected patients [30, 49]. Other features of neonatal hyperthyroidism like jaundice, hepatosplenomegaly, thrombocytopenia [41] and respiratory symptoms (such as apnea and asphyxia) [41, 45-47] were also observed in some patients. Neuromuscular symptoms have also been described [42]. The thyroid size was variable. Goiter was observed in approximately half the newborns and infants $[30,49]$. In children with later onset of disease and in those with delayed start of treatment, the risk of precocious puberty and short stature may complicate the disease course.

\section{How Is the Diagnosis of FNAH and PSNAH}

Established?

(1) In the presence of signs and symptoms of FNAH or PSNAH, it is recommended that first all index patients are investigated for the presence/absence of a TSHR germline mutation.

(2)If index patients display a TSHR germline mutation, all other family members, including asymptomatic and euthyroid family members, should be analysed for the mutation.

The goals of this strategy are to establish the diagnosis, to detect patients presymptomatically and to detect potential discrepancies between mutation status and clinical phenotypes.

(3) As most mutations associated with this condition are located in exon 10 of the TSHR gene, this exon should be screened initially; however, in case of discrepancies, the screening of exons 1-9 in addition to exon 10 is necessary. An additional search for further somatic constitutively activating mutations in hyperthyroid family members should be performed to explain possible discrepancies.
(4) Genetic counseling of the patients and apparently asymptomatic family members (mutation carriers) is recommended.

Quality of the evidence: high (+++) for 1, 3 and 4 and low (+) for 2; strength of recommendations: strong.

\section{Therapeutic Principles}

Treatment

Because of the rarity of the conditions, there are no randomized controlled trials in FNAH or PSNAH. However, well-characterized case series have provided valuable insights into different therapeutic options for these conditions. In both FNAH and PSNAH, incomplete ablation (subtotal thyroidectomy or non-ablative dose of radioiodine) or antithyroid drugs resulted in frequent relapses with the known pediatric complications of hyperthyroidism (see above) [44]. Moreover, although long-term treatment with antithyroid drugs can control hyperthyroidism, it has been reported to favour further thyroid enlargement [43]. In PSNAH, the time for recovery of the pituitary-thyroid feedback axis is unpredictable, and TSH may remain suppressed beyond the first year of life [40].

What Is the Optimal Treatment for FNAH?

(1) The complete ablation of the thyroid tissue by total thyroidectomy followed by radioiodine administration is strongly recommended.

(2) Antithyroid drugs should only be used to prepare the patients for surgery. $\beta$-Blocking drugs (propranolol) should be used in order to control adrenergic-like symptoms.

Quality of the evidence: moderate (++); strength of recommendations: strong.

What Is the Optimal Treatment for PSNAH?

(1) Total thyroid ablation is recommended to avoid the negative consequences of persistent or relapsing hyperthyroidism.

(2) Immediate treatment of overt neonatal hyperthyroidism with methimazole (not propylthiouracil because of its association with severe liver injury) is recommended for a good prognosis and for the prevention of advanced bone age or mental retardation.

(3) Surgery should be performed by a high-volume thyroid surgeon. In addition, early radioiodine treatment may be necessary to avoid relapses. Radioiodine treatment is recommended in children over 5 years.

(4) Long-term TSH suppression (beyond the 1st year of life) is likely. The time for recovery of the feedback axis 
is unpredictable. This should be taken into account when relapse of hyperthyroidism is suspected.

Quality of the evidence: moderate (++); strength of recommendations: strong.

\section{Disclosure Statement}

The authors declare that there are no conflicts of interests.

\section{References}

-1 Atkins D, Best D, Briss PA, Eccles M, FalckYtter Y, Flottorp S, et al: Grading quality of evidence and strength of recommendations. BMJ 2004;328:1490.

-2 Guyatt GH, Cook DJ, Jaeschke R, Pauker SG, Schunemann HJ: Grades of recommendation for antithrombotic agents: American College of Chest Physicians Evidence-Based Clinical Practice Guidelines (8th Edition). Chest 2008;133(6 suppl):123S-131S.

$>3$ Fuhrer D, Warner J, Sequeira M, Paschke R, Gregory J, Ludgate M: Novel TSHR germline mutation (Met463Val) masquerading as Graves' disease in a large Welsh kindred with hyperthyroidism. Thyroid 2000;10:10351041.

4 Vaidya B, Campbell V, Tripp JH, Spyer G, Hattersley AT, Ellard S: Premature birth and low birth weight associated with nonautoimmune hyperthyroidism due to an activating thyrotropin receptor gene mutation. Clin Endocrinol (Oxf) 2004;60:711-718.

5 Nwosu BU, Gourgiotis L, Gershengorn MC, Neumann S: A novel activating mutation in transmembrane helix 6 of the thyrotropin receptor as cause of hereditary nonautoimmune hyperthyroidism. Thyroid 2006;16: 505-512.

-6 Horton GL, Scazziga B: Hereditary hyperthyroidism with diffuse non autoimmune hyperactivity due to autonomy of function and growth. Ann Endocrinol (Paris) 1987; 48:92.

$>7$ Tonacchera M, Van Sande J, Cetani F, Swillens S, Schvartz C, Winiszewski P, et al: Functional characteristics of three new germline mutations of the thyrotropin receptor gene causing autosomal dominant toxic thyroid hyperplasia. J Clin Endocrinol Metab 1996;81:547-554.

$\checkmark 8$ Schwab KO, Gerlich M, Broecker M, Sohlemann P, Derwahl M, Lohse MJ: Constitutively active germline mutation of the thyrotropin receptor gene as a cause of congenital hyperthyroidism. J Pediatr 1997;131:899904.

$>9$ Fuhrer D, Wonerow $\mathrm{P}$, Willgerodt $\mathrm{H}$, Paschke $\mathrm{R}$ : Identification of a new thyrotropin receptor germline mutation (Leu629Phe) in a family with neonatal onset of autosomal dominant nonautoimmune hyperthyroidism. J Clin Endocrinol Metab 1997;82:4234-4238.
10 Khoo DH, Parma J, Rajasoorya C, Ho SC, Vassart G: A germline mutation of the thyrotropin receptor gene associated with thyrotoxicosis and mitral valve prolapse in a Chinese family. J Clin Endocrinol Metab 1999; 84:1459-1462.

11 Alberti L, Proverbio MC, Costagliola S, Weber G, Beck-Peccoz P, Chiumello G, et al: A novel germline mutation in the TSH receptor gene causes non-autoimmune autosomal dominant hyperthyroidism. Eur J Endocrinol 2001;145:249-254.

12 Arturi F, Chiefari E, Tumino S, Russo D, Squatrito S, Chazenbalk G, et al: Similarities and differences in the phenotype of members of an Italian family with hereditary nonautoimmune hyperthyroidism associated with an activating TSH receptor germline mutation. J Endocrinol Invest 2002;25:696701.

13 Claus M, Maier J, Paschke R, Kujat C, Stumvoll M, Fuhrer D: Novel thyrotropin receptor germline mutation (Ile568Val) in a Saxonian family with hereditary nonautoimmune hyperthyroidism. Thyroid 2005;15:1089-1094.

14 Karges B, Krause G, Homoki J, Debatin KM, de Roux N, Karges W: TSH receptor mutation V509A causes familial hyperthyroidism by release of interhelical constraints between transmembrane helices TMH3 and TMH5. J Endocrinol 2005; 186:377-385.

15 Nishihara E, Nagayama Y, Amino N, Hishinuma A, Takano T, Yoshida H, et al: A novel thyrotropin receptor germline mutation (Asp617Tyr) causing hereditary hyperthyroidism. Endocr J 2007;54:927-934.

16 Liu Z, Sun Y, Dong Q, He M, Cheng CH, Fan F: A novel TSHR gene mutation (Ile691Phe) in a Chinese family causing autosomal dominant non-autoimmune hyperthyroidism. J Hum Genet 2008;53:475-478.

17 Fukata S, Hishinuma A, Nakatake H, Tajiri $\mathrm{J}$ : A Japanese family with familial nonautoimmune hyperthyroidism with a novel mutation (Asn406Ser) in extracellular domain of thyrotropin receptor. Clin Endocrinol (Oxf) 2012;77:329-330.

18 Winkler F, Kleinau G, Tarnow P, Rediger A, Grohmann L, Gaetjens I, et al: A new phenotype of nongoitrous and nonautoimmune hyperthyroidism caused by a heterozygous thyrotropin receptor mutation in transmembrane helix 6. J Clin Endocrinol Metab 2010; 95:3605-3610.
19 Duprez L, Parma J, Van Sande J, Allgeier A, Leclere J, Schvartz C, et al: Germline mutations in the thyrotropin receptor gene cause non-autoimmune autosomal dominant hyperthyroidism. Nat Genet 1994;7:396-401.

20 Lee YS, Poh L, Loke KY: An activating mutation of the thyrotropin receptor gene in hereditary non-autoimmune hyperthyroidism. J Pediatr Endocrinol Metab 2002;15: 211-215.

-21 Gozu HI, Lublinghoff J, Bircan R, Paschke R Genetics and phenomics of inherited and sporadic non-autoimmune hyperthyroidism. Mol Cell Endocrinol 2010;322:125-134.

-22 Kopp P, van Sande J, Parma J, Duprez L, Gerber H, Joss E, et al: Brief report: congenital hyperthyroidism caused by a mutation in the thyrotropin-receptor gene. N Engl J Med 1995;332:150-154.

23 Holzapfel HP, Wonerow P, von Petrykowski W, Henschen M, Scherbaum WA, Paschke R: Sporadic congenital hyperthyroidism due to a spontaneous germline mutation in the thyrotropin receptor gene. J Clin Endocrinol Metab 1997;82:3879-3884.

24 Kopp P, Jameson JL, Roe TF: Congenital nonautoimmune hyperthyroidism in a nonidentical twin caused by a sporadic germline mutation in the thyrotropin receptor gene. Thyroid 1997;7:765-770.

-25 Esapa CT, Duprez L, Ludgate M, Mustafa MS, Kendall-Taylor P, Vassart G, et al: A novel thyrotropin receptor mutation in an infant with severe thyrotoxicosis. Thyroid 1999;9: 1005-1010.

26 Tonacchera M, Agretti P, Rosellini V, Ceccarini G, Perri A, Zampolli M, et al: Sporadic nonautoimmune congenital hyperthyroidism due to a strong activating mutation of the thyrotropin receptor gene. Thyroid 2000;10:859-863.

27 Biebermann H, Winkler F, Handke D, Gruters A, Krude H, Kleinau G: Molecular description of non-autoimmune hyperthyroidism at a neonate caused by a new thyrotropin receptor germline mutation. Thyroid Res 2011;4(suppl 1):S8.

28 Watkins MG, Dejkhamron P, Huo J, Vazquez DM, Menon RK: Persistent neonatal thyrotoxicosis in a neonate secondary to a rare thyroid-stimulating hormone receptor activating mutation: case report and literature review. Endocr Pract 2008;14:479-483. 
-29 Bertalan R, Sallai A, Solyom J, Lotz G, Szabo I, Kovacs B, et al: Hyperthyroidism caused by a germline activating mutation of the thyrotropin receptor gene: difficulties in diagnosis and therapy. Thyroid 2010;20:327-332.

30 Lueblinghoff J, Mueller S, Sontheimer J, Paschke R: Lack of consistent association of thyrotropin receptor mutations in vitro activity with the clinical course of patients with sporadic non-autoimmune hyperthyroidism. J Endocrinol Invest 2010;33:228-233.

- 31 Hebrant A, van Staveren WC, Maenhaut C, Dumont JE, Leclere J: Genetic hyperthyroidism: hyperthyroidism due to activating TSHR mutations. Eur J Endocrinol 2011;164: $1-9$.

32 Thomas JS, Leclere J, Hartemann P, Duheille J, Orgiazzi J, Petersen M, et al: Familial hyperthyroidism without evidence of autoimmunity. Acta Endocrinol (Copenh) 1982; 100:512-518.

-33 Biebermann H, Schoneberg T, Hess C, Germak J, Gudermann T, Gruters A: The first activating TSH receptor mutation in transmembrane domain 1 identified in a family with nonautoimmune hyperthyroidism. J Clin Endocrinol Metab 2001;86:4429-4433.

- 34 Supornsilchai V, Sahakitrungruang T, Wongjitrat N, Wacharasindhu S, Suphapeetiporn K, Shotelersuk V: Expanding clinical spectrum of non-autoimmune hyperthyroidism due to an activating germline mutation, p.M453T, in the thyrotropin receptor gene. Clin Endocrinol (Oxf) 2009;70:623628.

- 35 Ferrara AM, Capalbo D, Rossi G, Capuano S, Del Prete G, Esposito V, et al: A new case of familial nonautoimmune hyperthyroidism caused by the M463V mutation in the TSH receptor with anticipation of the disease across generations: a possible role of iodine supplementation. Thyroid 2007;17:677-680.

- 36 Akcurin S, Turkkahraman D, Tysoe C, Ellard S, De Leener A, Vassart G, et al: A family with a novel TSH receptor activating germline mutation (p.Ala485Val). Eur J Pediatr 2008; 167:1231-1237.

37 Pohlenz J, Pfarr N, Kruger S, Hesse V: Subclinical hyperthyroidism due to a thyrotropin receptor (TSHR) gene mutation (S505R). Acta Paediatr 2006;95:1685-1687.

- 38 Nishihara E, Chen CR, Higashiyama T, Mizutori-Sasai Y, Ito M, Kubota S, et al: Subclinical nonautoimmune hyperthyroidism in a family segregates with a thyrotropin receptor mutation with weakly increased constitutive activity. Thyroid 2010;20:13071314.
39 Ringkananont U, Van Durme J, Montanelli L, Ugrasbul F, Yu YM, Weiss RE, et al: Repulsive separation of the cytoplasmic ends of transmembrane helices 3 and 6 is linked to receptor activation in a novel thyrotropin receptor mutant (M626I). Mol Endocrinol 2006;20:893-903.

-40 Jaeschke H, Eszlinger M, Lueblinghoff J, Coslovsky R, Paschke R: Prolonged inappropriate TSH suppression during hypothyroidism after thyroid ablation in a patient with nonautoimmune familial hyperthyroidism. Horm Metab Res 2011;43:500-504.

41 de Roux N, Polak M, Couet J, Leger J, Czernichow P, Milgrom E, et al: A neomutation of the thyroid-stimulating hormone receptor in a severe neonatal hyperthyroidism. J Clin Endocrinol Metab 1996;81:2023-2026.

42 Elgadi A, Arvidsson CG, Janson A, Marcus C, Costagliola S, Norgren S: Autosomaldominant non-autoimmune hyperthyroidism presenting with neuromuscular symptoms. Acta Paediatr 2005;94:1145-1148.

43 Nishihara E, Fukata S, Hishinuma A, Kudo $\mathrm{T}$, Ohye H, Ito M, et al: Sporadic congenital hyperthyroidism due to a germline mutation in the thyrotropin receptor gene (Leu 512 Gln) in a Japanese patient. Endocr J 2006;53: 735-740.

44 Bircan R, Miehle K, Mladenova G, Ivanova R, Sarafova A, Borissova AM, et al: Multiple relapses of hyperthyroidism after thyroid surgeries in a patient with long term followup of sporadic non-autoimmune hyperthyroidism. Exp Clin Endocrinol Diabetes 2008; 116:341-346.

45 Borgel K, Pohlenz J, Koch HG, Bramswig JH: Long-term carbimazole treatment of neonatal nonautoimmune hyperthyroidism due to a new activating TSH receptor gene mutation (Ala428Val). Horm Res 2005;64:203-208.

46 Chester J, Rotenstein D, Ringkananont U, Steuer G, Carlin B, Stewart L, et al: Congenital neonatal hyperthyroidism caused by germline mutations in the TSH receptor gene. J Pediatr Endocrinol Metab 2008;21: 479-486.

47 Lavard L, Sehested A, Brock Jacobsen B, Muller J, Perrild H, Feldt-Rasmussen U, et al: Long-term follow-up of an infant with thyrotoxicosis due to germline mutation of the TSH receptor gene (Met453Thr). Horm Res 1999;51:43-46.
48 Fuhrer D, Mix M, Wonerow P, Richter I, Willgerodt $\mathrm{H}$, Paschke R: Variable phenotype associated with Ser505Asn-activating thyrotropin-receptor germline mutation. Thyroid 1999;9:757-761.

- 49 Aycan Z, Agladioglu SY, Ceylaner S, Cetinkaya S, Bas VN, Kendirici HN: Sporadic nonautoimmune neonatal hyperthyroidism due to $\mathrm{A} 623 \mathrm{~V}$ germline mutation in the thyrotropin receptor gene. J Clin Res Pediatr Endocrinol 2010;2:168-172.

50 Paschke R, Ludgate M: The thyrotropin receptor in thyroid diseases. N Engl J Med 1997;337:1675-1681.

51 Kopp P: The TSH receptor and its role in thyroid disease. Cell Mol Life Sci 2001;58:13011322.

52 Lueblinghoff J, Eszlinger M, Jaeschke H, Mueller S, Bircan R, Gozu H, et al: Shared sporadic and somatic thyrotropin receptor mutations display more active in vitro activities than familial thyrotropin receptor mutations. Thyroid 2011;21:221-229.

- 53 Mueller S, Jaeschke H, Paschke R: Current standards, variations, and pitfalls for the determination of constitutive TSHR activity in vitro. Methods Enzymol 2010;485:421-436.

54 Mueller S, Gozu HI, Bircan R, Jaeschke H, Eszlinger M, Lueblinghoff J, et al: Cases of borderline in vitro constitutive thyrotropin receptor activity: how to decide whether a thyrotropin receptor mutation is constitutively active or not? Thyroid 2009;19:765773

55 Jaeschke H, Mueller S, Eszlinger M, Paschke $\mathrm{R}$ : Lack of in vitro constitutive activity for four previously reported TSH receptor mutations identified in patients with nonautoimmune hyperthyroidism and hot thyroid carcinomas. Clin Endocrinol (Oxf) 2010;73: 815-820.

56 Gozu HI, Mueller S, Bircan R, Krohn K, Ekinci G, Yavuzer D, et al: A new silent germline mutation of the TSH receptor: coexpression in a hyperthyroid family member with a second activating somatic mutation. Thyroid 2008; 18:499-508.

57 Schaarschmidt J, Paschke S, Özerden M, Jäschke $\mathrm{H}$, Huth S, Eszlinger M, Meller J, Paschke R: Late manifestation of subclinical hyperthyroidism after goitrogenesis in an index patient with a N670S TSH receptor germline mutation masquerading as TSH receptor antibody negative Graves' disease. Horm Metab Res 2012, E-pub ahead of print. 